\title{
Effect of Caesalpinia bonduc Polyphenol Extract on Alloxan-Induced Diabetic Rats in Attenuating Hyperglycemia by Upregulating Insulin Secretion and Inhibiting JNK Signaling Pathway
}

\author{
Asra Iftikhar, ${ }^{1,2}$ Bilal Aslam $\mathbb{D}^{2},{ }^{2}$ Maryam Iftikhar, ${ }^{3}$ Wafa Majeed, ${ }^{2}$ Mehwish Batool, ${ }^{1}$ \\ Bushra Zahoor, ${ }^{1}$ Naseem Amna, ${ }^{1}$ Hareem Gohar, ${ }^{1}$ and Iqra Latif ${ }^{1}$ \\ ${ }^{1}$ Faculty of Pharmaceutical Sciences, The University of Faisalabad, Faisalabad 38000, Pakistan \\ ${ }^{2}$ Institutes of Pharmacy, Physiology and Pharmacology, University of Agriculture, Faisalabad 38000, Pakistan \\ ${ }^{3}$ Innovation Center for Food Nutrition and Human Health, Beijing Engineering and Technology Research Center of Food Additives, \\ Laboratory of Molecular Sensory Science, Beijing Technology \& Business University, Beijing 100048, China \\ Correspondence should be addressed to Bilal Aslam; cba933@gmail.com
}

Received 8 October 2019; Revised 29 February 2020; Accepted 2 March 2020; Published 17 March 2020

Academic Editor: Marco Malaguti

Copyright ( 2020 Asra Iftikhar et al. This is an open access article distributed under the Creative Commons Attribution License, which permits unrestricted use, distribution, and reproduction in any medium, provided the original work is properly cited.

\begin{abstract}
Caesalpinia bonduc has been used in herbal medicines for the treatment of a wide range of diseases from decades. The present study has explored the remedial potential and underlying mechanism of polyphenol extract of Caesalpinia bonduc in alloxanized diabetic rats. HPLC/MS analysis confirmed the presence of phenolics in considerable concentrations in Caesalpinia bonduc extract. Administration of different doses $(250$ and $500 \mathrm{mg} / \mathrm{kg}$ ) of CPP extract to hyperglycemic rats for 8 weeks restored blood and serum glucose, insulin, glycosylated hemoglobin, leptin, amylin, and carbohydrate metabolizing enzymes level towards normal compared to alloxanized diabetic group. The effect of CPP extract on various genes such as Pdx-1, Ins-1, ngn-3, GLUT-4, and IRS-1 in insulin signaling pathway and Traf-4, Traf-6, and Mapk-8 in MAPK downstream JNK cascade was examined through qRT-PCR to access the core molecular mechanism involved in CPP-induced recovery of diabetes. Results have revealed that $\mathrm{CPP}$ extract reduced oxidative stress in pancreatic $\beta$ cells by restoring free radical scavenging potential, reducing the mRNA expression of Mapk-8, Traf-4, and Traf-6, and increasing the Pdx-1, Ins-1, ngn-3, GLUT-4, and IRS-1 expression ensuing regeneration of $\beta$ cells and subsequent insulin release from pancreas. The results obtained in this study recommend that $\mathrm{CPP}$ extract may be a promising therapeutic restorative agent in the treatment of diabetes mellitus.
\end{abstract}

\section{Introduction}

Diabetes mellitus is a complex metabolic disorder characterized by hyperglycemia, pancreatic beta $(\beta)$ cells dysfunction, and abnormal lipid profile that result from metabolic deregulations, impaired insulin secretion and action, and inappropriate consumption of glucose [1]. It is one of the most prevalent chronic diseases and leads towards severe complications such as increase in production of reactive oxygen species (ROS), impairment of antioxidant enzymes [2], hyperglycemia [3], dislipidemia [4], alteration in insulin signaling pathway, and ROS-induced cellular damage [5]. All these changes will result in diabetes-associated secondary complications like nephropathy, retinopathy, neuropathy, and cardiovascular morbidity [6].

Experimental and clinical research studies have proved strong relation between oxidative stress induced by hyperglycemia and diabetes as ROS are produced in excessive amount through the oxidation of glucose [7]. Furthermore, pancreatic $\beta$ cells are attacked by excessive ROS with the consequence of cellular damage due to weak intrinsic free radical scavenging potential [8]. Several signaling pathways are also altered by oxidative stress resulting in the release of proinflammatory cytokines, formation of advanced glycation end 
products (AGEs), and cell death [9]. Therefore, interference in oxidative stress has been highlighted as an important strategy for treatment of diabetes [10].

Oral antihyperglycemic agents are being used for glycemic control, but they have severe adverse effects such as abdominal pain, obesity, hepatic disorders, and renal injury $[11,12]$. According to latest research, plant-derived products have demonstrated wide range of valuable therapeutic activities without causing adverse effects [11]. Plants rich in polyphenolics have gained much attention due to their wide spectrum of therapeutic benefits, as verified by both in vitro and in vivo studies $[12,13]$. The polyphenols are reported to produce insulin-like effect in glucose consumption, lower ROS generation, and enhance free radical scavenging mechanism [14]. These phytoconstituents protect cellular antioxidant defense mechanism from oxidative stress, stimulate insulin signaling pathway, and regulate transcription factors, hormones, peptides, and inflammatory pathways for the management of hyperglycemic condition and diabetes-associated complications [15].

Caesalpinia bonduc (L.) Roxb. also known as "fever nut, bonduc nut and nicker nut" belongs to the family of Caesalpiniaceae and has been reported in folk medicine $[16,17]$. It is a thorny perennial shrub, native of Africa, South India, Sri Lanka, Malaysia, Burma, and Ceylon, particularly along the sea coast and up to $2500 \mathrm{ft}$. in hilly areas. Caesalpinia bonduc (C. bonduc) has a wide range of therapeutic effects like antioxidant, antiviral, antianaphylactic, antipyretic, antibacterial, antidiarrheal, and antiasthamatic potential $[18,19]$. These effects are due to the presence of phytoconstituents such as polyphenols, flavonoids, saponins, and terpenoids in different parts of $\mathrm{C}$. bonduc such as leaves, roots, seeds, and bark. However, leaves are a rich source of polyphenol content [20]. Phenolic compounds produce antioxidant effect and reduce oxidative stress by donating hydrogen ions. Keeping in view the pharmacological activities of polyphenols, we hypothesized that polyphenols extracted from C. bonduc may improve hyperglycemic status of alloxan-induced diabetic rats through reduction/inhibition of oxidative damage and by restoration of pancreas and liver function by normalizing the activity of genes involved in insulin release and MAP kinase downstream JNK cascade.

\section{Materials and Methods}

2.1. The Extraction Procedure of Polyphenolics. Leaves of C. bonduc were collected from a local market and verified for taxonomy from the Department of Botany, and a voucher specimen (reference no.: 21148) was deposited in the herbarium of University of Agriculture, Faisalabad. For the preparation of extract, $500 \mathrm{~g}$ of $\mathrm{C}$. bonduc leaves were desiccated, pulverized, and extracted with $70 \%$ ethanol. The obtained extract was kept at $25^{\circ} \mathrm{C}$ for 7 days. After 7 days, the mixture was filtered and the solvent was completely removed using a rotary evaporator. The residue obtained after extraction was mixed with water and extracted with petroleum ether. Treatment of residue with petroleum ether results in the formation of two separate layers. Ethyl acetate with glacial acetic acid $(10 \mathrm{~mL} / \mathrm{L})$ was used to extract the aqueous layer. Organic layer was evaporated and polyphenols were extracted out from ethyl acetate layer and dried through evaporation [21]. The C. bonduc polyphenol (CPP) extract was then freeze dried $\left(-58^{\circ} \mathrm{C}\right)$ and kept for further analysis.

2.2. Assessment of Total Polyphenol and Flavonoid Content of CPP Extract. The total polyphenol concentration in CPP extract was determined by the Folin-Ciocalteu (FC) colorimetric method with some modifications [21]. The absorbance was deliberate spectrophotometrically at $760 \mathrm{~nm}$. Results were presented as mg gallic acid equivalents (GAE)/100 g dry weight (DW). The total flavonoid concentration was estimated by the aluminium chloride colorimetric method [22]. The absorbance was measured at $510 \mathrm{~nm}$ and the results were expressed as $\mathrm{mg}$ of $(+)$ - catechin equivalents (CE)/100 g DW.

2.3. Quantification of Polyphenols in CPP Extract by HPLCMass Spectrometry (HPLC/MS). The CPP extract was assayed through HPLC-MS (Agilent Technologies, USA). Different components of extract were separated using C-18 column $(4.6 \times 250 \mathrm{~mm}$ and $5 \mu \mathrm{m}$, Agilent, USA). Mobile phase A was consisted of $2 \%(v / v)$ glacial acetic acid and B was acetonitrile. Analysis conditions were as follows: $10 \% \mathrm{~B}, 10 \mathrm{~min}$; $25 \% \mathrm{~B}, 15 \mathrm{~min} ; 50 \% \mathrm{~B}, 45 \mathrm{~min} ; 75 \% \mathrm{~B}, 65 \mathrm{~min}$; and $100 \% \mathrm{~B}$, $75 \mathrm{~min}$. The temperature of column was $28^{\circ} \mathrm{C}$, flow rate was $1 \mathrm{~mL} / \mathrm{min}$ and the volume of injection was $20 \mu \mathrm{L}$. Absorbance wavelength was adjusted at 280-310 $\mathrm{nm}$ for the detection of phenolics using UV detector [23]. At least three independent polyphenol extractions were performed and analyzed independently by HPLC-MS. Phenolic compounds were quantified by comparing the peak area of each compound with a respective standard.

2.4. Experiment Animals. Male adult Wistar albino rats weighing 250 to $300 \mathrm{~g}$ (7-8 weeks old) were obtained from the University of Agriculture (Faisalabad, Pakistan) and kept under standard laboratory conditions (at room temperature and $12 \mathrm{~h}$ light-dark cycle) with ad libitum approach to water and pellet diet. The animals were acclimatized for a period of seven days prior to the experiment. The experiment protocol was approved by the ethical review committee (ethical review no.: 511/oric). The research study was designed and conducted in accordance with the procedures of the graduate studies research board (GSRB) and international standards for the handling of experimental animals.

2.5. Experimental Design. Alloxan monohydrate $(120 \mathrm{mg} / \mathrm{kg})$ mixed with normal saline $(0.9 \%$ saline $)$ was injected intraperitoneally to overnight-fasted rats except control group for the induction of diabetes. After one week, blood glucose levels of rats of all groups were observed by an Accu-Chek glucometer (Roche Diagnostic, Germany) from the tail vein. The animals with a glucose level equal to or more than $300 \mathrm{mg} / \mathrm{dL}$ were included in the study. Blood glucose levels were checked on a weekly basis for 8 weeks in order to observe the hyperglycemic status and also to examine the effects of CPP extract on 
alloxanized hyperglycemic rats. Rats were grouped into four groups ( $n=15$ per group) as follows:

Group 1: control receiving routine diet,

Group 2: positive control (diabetic) administered normal saline $(1.5 \mathrm{~mL} / \mathrm{kg}$, ip),

Group 3: diabetic group treated with CPP extract (250 mg/kg),

Group 4: diabetic group treated with CPP extract (500 mg/kg).

After 8 weeks of experiment, the rats were fasted overnight, anaesthetized with $3 \%$ sodium pentobarbital (ip), and sacrificed. Blood samples from each rat were collected and divided into two parts. One part (about $1 \mathrm{~mL}$ ) was kept in heparinized tubes for estimation of glycosylated hemoglobin (HbA1c), and the remaining part in nonheparinized tubes was centrifuged at $1400 \mathrm{~g}$ for $10 \mathrm{~min}$ for the separation of serum. The serum samples were separated and kept at $-20^{\circ} \mathrm{C}$ until used for further analyses. For histopathological assessment, sections of rat's pancreas were preserved in $10 \%$ neutral buffered formalin (NBF). For gene expression analysis, rat's pancreatic and hepatic tissues were snapfrozen in liquid nitrogen, then immediately ground in a sterilized autoclaved mortar and pestle for further analysis.

2.6. Preparation of Tissue Homogenate. The excised tissues of some rats of all groups were homogenized with $10 \%(w / v)$ buffer (50 mM Tris- $\mathrm{HCl}, 1.15 \% \mathrm{KCl} \mathrm{pH} \mathrm{7.4)} \mathrm{and} \mathrm{centrifuged}$ at $9000 \mathrm{~g}$ for $3 \mathrm{~min}$ at $4^{\circ} \mathrm{C}$ using refrigerated centrifuge. The obtained supernatants were collected as tissue homogenate and used for the biochemical evaluation. The protein concentration of obtained homogenate was analyzed according to the procedure of [24].

2.7. Biochemical Examination. The fasting blood glucose level in normal, diabetic, and treated groups of rats were measured on a weekly basis during 8 weeks of experiment through the tail prick method using a glucometer. After 8 weeks of experiment, serum glucose levels of all groups were analyzed with the use of the rat glucose assay kit (81693, Crystal Chem, USA). Serum insulin levels were observed through enzymelinked immunosorbent assay (ELISA) using the rat insulin ELISA kit (ELR-Insulin, RayBio ${ }^{\circledR}$, Norcross, GA, USA), and the glycosylated hemoglobin level was determined by a commercially available kit (MBS2033689, My BioSure, California, USA). Serum leptin and peptide YY (PYY) levels were also assayed through ELISA kits (ab100773, Abcam, Cambridge, UK \& EIAR-PYY, RayBio ${ }^{\circledR}$, Norcross, GA, USA). The serum amylin level was determined through the rat amylin assay kit (NBP2-76735, Novus Biologicals, USA) and absorbance was deliberated at $476 \mathrm{~nm}$ wavelength. The liver glycogen level was assayed in accordance with the procedure of [25]. Activities of glycolytic enzymes (glucose-6-phosphate dehydrogenase and hepatic hexokinase) were measured by kits provided by Abcam (ab102529, ab136957, Abcam, Cambridge, UK), and gluconeogenic enzymes such as fructose1,6-bisphosphatase and glucose-6-phosphatase were assayed using the commercially available ELISA kits (MBS931493 and MBS749461, My BioSure, California, USA).
2.8. Estimation of Intracellular ROS and Measurement of Lipid per Oxidation. Concentration of intracellular reactive oxygen species (ROS) was examined by using 2,7-dichlorofluorescein diacetate (DCF-DA) as a probe through the procedure of [26]. The development of DCF was determined with the help of a fluorescence spectrometer equipped with a FITC filter between the wavelengths of 488 to $510 \mathrm{~nm}$ for $10 \mathrm{~min}$. Lipid peroxidation was examined in the form of malondialdehyde (MDA) using the thiobarbituric acid reactive substances (TBARS) assay kit by adopting the method of [27]. The absorbance of TBARS produced was calibrated using a spectrophotometer at $532 \mathrm{~nm}$, and the results were expressed in nmol MDA/mg protein.

2.9. Assessment of Antioxidant Defense Activities. Superoxide dismutase (SOD) activity was accessed in hepatic and pancreatic tissue homogenates of all experimental groups of rats by the procedure of [28] and then tailored by [29]. Concentration of catalase (CAT) was determined by the procedure of [30] and expressed in $\mu \mathrm{mol}$ of $\mathrm{H}_{2} \mathrm{O}_{2}$ decomposed/$\mathrm{min} / \mathrm{mg}$ of protein. Glutathione peroxidase $(\mathrm{GPx})$ enzyme level was analyzed by the procedure described by [31] and expressed in terms of nmol of glutathione oxidized $/ \mathrm{min} / \mathrm{mg}$ of protein. Reduced glutathione (GR) enzyme activity was examined by adopting the procedure of [32] with modifications, and the results were stated in terms of $\mathrm{mg} / \mathrm{dL}$ of tissue.

2.10. Histopathological Examination. The pancreas of rats were dissected out after animal sacrifice, fixed in 10\% neutral buffered formalin $(\mathrm{NBF})$, and entrenched in paraffin. After embedding, the tissue samples were sliced with microtome into transparent and $5 \mu \mathrm{m}$ thick slices, placed on glass slide, and stained with hematoxylin and eosin for microscopic investigation [33].

2.11. RNA Extraction and Real-Time Quantitative PCR. RNA extraction was carried out by the TRIzol method (Thermo Fisher Scientific, Waltham, Massachusetts, USA) [34], modified according to [35] and quantified on a NanoDrop. The total isolated mRNA was reverse-transcribed to cDNA by using the RevertAid cDNA synthesis kit (Thermo Fisher Scientific) according to the manufacturer's manual. Real-time qPCR (RT-qPCR) was carried out on the iQ5 Bio-Rad machine using Maxima SYBR Green/ROX qRT-PCR Master Mix (Thermo Fisher Scientific). Expressions of the following genes were studied: Pdx-1, ngn-3, Ins-1, MapK-8, Traf-4, Traf-6, IRS-1, and GLUT-4. The reference/housekeeping gene was $\beta$-actin. The PCR was done for 40 cycles of twostep cDNA denaturation at $95^{\circ} \mathrm{C}$ for 15 seconds, annealing for 25 seconds at $52^{\circ} \mathrm{C}$, and the extension time was $20 \mathrm{sec}$ onds at $72^{\circ} \mathrm{C}$. Particular primer sequences were used for the amplification of genes (Table 1) in reaction mixture. The data was analyzed by the $2^{-\Delta \Delta \mathrm{Ct}}$ method.

2.12. Statistical Analysis. All results were expressed as mean \pm SE. Data was statistically analyzed using one-way ANOVA followed by the Duncan multiple range (DMR) test. $P \leq 0.05$ was considered statistically significant. 
TABle 1: Primer sequences of genes used for RT-qPCR.

\begin{tabular}{lcc}
\hline $\begin{array}{l}\text { Gene number/ } \\
\text { name }\end{array}$ & Primer sequence $\left(5^{\prime}\right.$ to $\left.3^{\prime}\right)$ & Direction \\
\hline Traf-6 & $\begin{array}{c}\text { GCGCCTAGTAAGACAGGACC } \\
\text { CACATGCATGCTCTGCGTTT }\end{array}$ & $\begin{array}{c}\text { Forward } \\
\text { Reverse }\end{array}$ \\
\hline \multirow{2}{*}{ Mapk-8 } & CTCAGCATCCGGTCTCTTCG & Forward \\
& CTGCTGTCTGTATCCGAGGC & Reverse \\
\hline \multirow{2}{*}{ Traf-4 } & CGACTACAAGTTCCTGGAGAAGC & Forward \\
& AGGTGTCGCAGAAGCGGTG & Reverse \\
\hline \multirow{2}{*}{ Pdx-1 } & TCCCGAATGGAACCGAGACT & Forward \\
& TTCATCCACGGGAAAGGGAG & Reverse \\
\hline \multirow{2}{*}{ Ins-1 } & AGGCTCTGTACCTGGTGTGTG & Forward \\
& CGGGTCCTCCACTTCACGAC & Reverse \\
\hline \multirow{2}{*}{ Ngn-3 } & TGCAGCCACATCAAACTCTC & Forward \\
& GGTCACCCTGGAAAAAGTGA & Reverse \\
\hline \multirow{2}{*}{ IRS-1 } & GATACCGATGGCTTCTCAGACG & Forward \\
& TCGTTCTCATAATACTCCAGGCG & Reverse \\
\hline \multirow{2}{*}{ GLUT-4 } & ACTCTTGCCACACAGGCTCT & Forward \\
& AATGGAGACTGATGCGCTCT & Reverse \\
\hline \multirow{2}{*}{ Ceta action } & TATCGTCATCCATGGCGAACTG & Reverse \\
\hline
\end{tabular}

\section{Results and Discussion}

3.1. Polyphenol Content in CPP Extract and Identification of Phenolic Compounds. Polyphenolic compounds are the most important class of phytochemicals that exhibit anti-inflammatory, antistress, and antihyperglycemic properties. The polyphenol concentration in the ethanol extract of $\mathrm{C}$. bonduc was found to be $119.7 \pm 3.5 \mathrm{mg}$ GAE/g (Table 2). The polyphenols in the ethanolic extract of $\mathrm{C}$. bonduc were separated by maceration, and the concentration of different phenolics in the extract was determined by using HPLC/MS. Gallic acid, protocatechuic acid, ferulic acid, chlorogenic acid, luteolin, p-coumaric acid, quercetin-3-methyl, caffeic acid, and epicatechin were the phenolic compounds identified in CPP extract (Table 3). Gallic acid content $(597 \pm 1.53 \mu \mathrm{g} / \mathrm{g})$ was more followed by caffeic acid $(387 \pm 5.16 \mu \mathrm{g} / \mathrm{g}), \mathrm{p}$-coumaric acid $(354 \pm 2.36 \mu \mathrm{g} / \mathrm{g})$, chlorogenic acid $(314 \pm 3.53)$, and protocatechuic acid $(302 \pm 2.14)$ in extract. The results have identified significant $(P \leq 0.05)$ high concentrations of gallic acid and caffeic acid in CPP

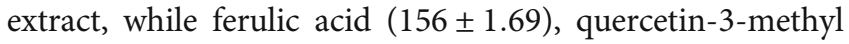
$(131 \pm 0.53)$, and luteolin $(76 \pm 1.03)$ contents were comparatively low (Table 3 ).

The results have shown the presence of significant $(P \leq 0.05)$ high amount of polyphenols in CPP extract. According to HPLC/MS, the concentrations of phenolic compounds were gallic acid $>$ caffeic acid $>$ p-coumaric acid $>$ chlorogenic acid $>$ protocatechuic acid $>$ epicatechin $>$ ferulic acid > quercetin-3-methyl > luteolin (Table 1). A lot of scientific research studies provide potential evidence about
TABLE 2: Total polyphenol and total flavonoid concentration present in CPP extract.

\begin{tabular}{lc}
\hline $\begin{array}{l}\text { Total polyphenols } \\
\text { (mg GAE/g sample) }\end{array}$ & $\begin{array}{c}\text { Total flavonoids } \\
(\mathrm{mg} \mathrm{CE} / \mathrm{g} \text { sample })\end{array}$ \\
\hline $119.7 \pm 3.5$ & $27 \pm 2.1$ \\
\hline
\end{tabular}

$\mathrm{GAE}=$ gallic acid, $\mathrm{CE}=$ catechin .

health benefits of polyphenol to humans. Particularly, gallic acid is reported to produce antioxidant effect by elevating the decreased levels of hepatic catalase enzyme and vitamin $\mathrm{C}$ in diabetic rats, and it also defend against damage produced by oxidative stress in hyperglycemic state [36, 37]. Caffeic acid potentially reduces weight loss, plasma glucose, and triglycerides levels and increases insulin concentration in diabetic rats [38]. Chlorogenic acid is also reported to have positive effects on glucose homeostasis, oxidative stress, inflammation, and apoptosis [39]. So the effect produced by each phenolic compound in CPP extract is responsible for the therapeutic potential of polyphenols. Thus, polyphenols protect against oxidative stress-mediated diseases. Results have also proved the potential hypoglycemic and lipidlowering medicinal value of CPP extract.

3.2. Assessment of Fasting Blood Glucose, Serum Glucose, Insulin, and Glycosylated Hemoglobin (HbA1c). Fasting blood glucose levels in the rats were observed weekly from week 0 to 8 throughout the experiment. According to results, there appeared a significant $(P \leq 0.05)$ rise in the glucose level after the induction of diabetes. But oral administration of CPP extract from week 1 to 8 in treated groups considerably $(P \leq 0.05)$ recovered the hyperglycemic state near to normal in both the time- and dose-dependent manners (Figure 1). Serum glucose level was also considerably $(P \leq 0.05)$ raised in all hyperglycemic rats compared to normal control group. However, treatment of diabetic groups 3 and 4 with 250 and $500 \mathrm{mg} / \mathrm{kg}$ CPP extract, respectively, significantly $(P \leq 0.05)$ reversed the upraised levels of serum glucose and insulin towards normal. The CPP treatment also significantly $(P \leq 0.05)$ ameliorated HbA1c levels towards normal compared to diabetic control rats (Table 4 ).

Glucose level in the body increases due to the destruction of glucose homeostasis resulting in increased HbAlc concentration and decreased level of insulin. Fasting blood glucose level is an established indicator of diabetes mellitus and its level was considerably raised in alloxanized hyperglycemic rats after the induction of diabetes. HbA1c is defined as glycation of glucose at one or more positions on the hemoglobin molecule. The International Diabetes Federation (IDF) has recommended that HbAlc is a nonmanipulatable and reliable biochemical parameter in the diagnosis of diabetes mellitus. However, fall in fasting blood glucose, serum glucose, and HbA1c levels and the improved serum insulin level predict the glucose lowering properties of the CPP extract. These results resemble previous research studies which have also identified the potent antidiabetic potential of phenolics [40]. 
TABle 3: Concentration of phytoconstituents present in CPP extract.

\begin{tabular}{lc}
\hline Phenolic constituent & $\mu \mathrm{g} / \mathrm{g}$ dry extract \\
\hline Gallic acid & $597 \pm 1.53$ \\
Protocatechuic acid & $302 \pm 2.14$ \\
Chlorogenic acid & $314 \pm 3.53$ \\
Ferulic acid & $156 \pm 1.69$ \\
Caffeic acid & $387 \pm 5.16$ \\
Luteolin & $76 \pm 1.03$ \\
Quercetin-3-methyl & $131 \pm 0.53$ \\
p-Coumaric acid & $354 \pm 2.36$ \\
Epicatechin & $257 \pm 1.47$ \\
\hline
\end{tabular}

Data presented as mean \pm SE $(n=3)$.

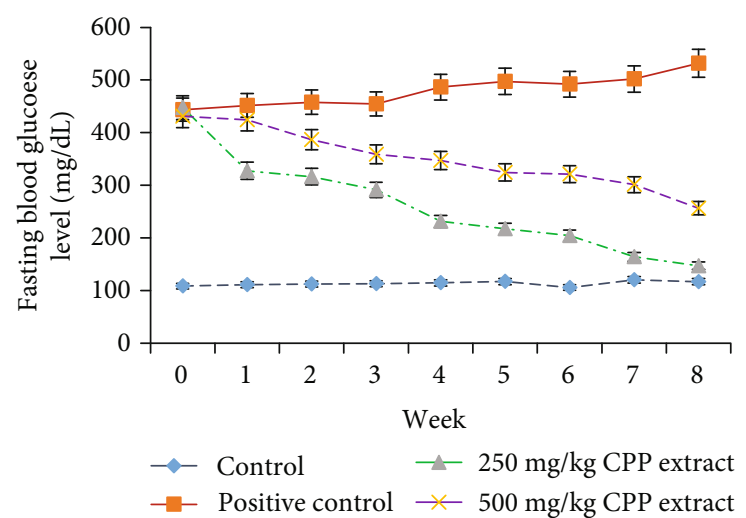

FIGURE 1: Role of CPP extract in reducing fasting blood glucose level in hyperglycemic rats.

3.3. Activities of Serum Leptin, Amylin and Peptide YY Levels. Table 5 shows the effect of 8 weeks CPP treatment (250 and $500 \mathrm{mg} / \mathrm{kg}$ ) on the activities of serum amylin, leptin, and PYY in the diabetic group of rats. In groups 3 and 4, the serum leptin level notably declined after treatment with CPP extract compared to the positive control. Oral administrations of CPP extract also significantly $(P \leq 0.05)$ repair serum amylin activity towards normal. Moreover, the serum PYY level was appreciably reinstated after treatment of hyperglycemic rats with $500 \mathrm{mg} / \mathrm{kg}$ of CPP extract compared to $250 \mathrm{mg} / \mathrm{kg}$.

Leptin is an important regulatory hormone of energy balance and body fat. It is an adipokine, which under normal physiological conditions functions to decrease appetite, regulate energy balance, and improve glucose consumption and insulin sensitivity [41]. Accumulating evidence indicates that leptin regulates energy expenditure by stimulating lipolysis in peripheral organs like skeletal muscle and adipose tissues and by reducing triglycerides content in liver [42, 43]. However, significant high concentration of leptin has been observed in diseased conditions such as obesity and hyperglycemia resulting in leptin resistance due to a reduced number of leptin receptors in peripheral organs. High serum leptin levels probably reflecting leptin resistance were seen in diabetic rats which predict an increased risk for diabetes. This may be because of deregulation of the adipocyte-insulin axis in pancreatic $\beta$ cells in a state of hyperleptinemia resulting in hyperinsulinemia [44]. Anabolic action of insulin stimulates adipogenesis thereby leading to a further increase in insulin secretion and consequently insulin resistance with the development of diabetes. However, by decreasing serum leptin, CPP extract significantly improved the diabetic conditions in treated groups 3 and 4 in a dose-dependent manner. Some studies have reported a significant positive relationship between insulin resistance, diabetes, and serum leptin level $[45,46]$. However, an inverse relation between serum leptin level and diabetes has also been reported [47].

PYY is a gut hormone that gets released in response to food in the ileum and colon and works to lessen hunger and to promote weight loss by slowing down gastric motility. According to results, high PYY levels in diabetic rats that may be correlated with unresponsive leptin signaling cascade as demonstrated due to leptin resistant. However, CPP extract significantly $(P \leq 0.05)$ reversed the PYY level in the diabetic group of rats. Serum amylin level was also raised to some extant in alloxan-induced diabetic rats. Accumulating evidence indicates that increased amylin level is associated with the activation of JNK cascade, production of oxidative stress, and ultimately apoptosis of $\beta$ cells of pancreas $[48,49]$. Moreover, another research study has proved that treatment of INS-1 cells with amylin significantly $(P \leq 0.05)$ increased autophagosome formation and cell death [50]. So amylin level could be considered as important target for the regeneration of $\beta$ cells and treatment of diabetes. This argument is based on the fact that increased amylin level is connected with the apoptosis of $\beta$ cells [51]. However, CPP extract considerably reversed the serum amylin level in treated groups. Indeed, different plant extracts have the ability to lower the amylin production $[52,53]$.

3.4. Estimation of Carbohydrate Metabolic Enzymes and Hepatic Glycogen. Table 6 demonstrates the effect of 8 weeks CPP treatment (250 and $500 \mathrm{mg} / \mathrm{kg}$ ) on the levels of carbohydrate metabolizing enzymes in the liver of hyperglycemic rats. Alloxan produced considerable deterioration in the activities of glucose-6-phosphate dehydrogenase and hexokinase and a significant $(P \leq 0.05)$ decline in hepatic glycogen level, whereas a considerable rise in the level of gluconeogenic enzymes was noticed. However, treatment of alloxanized hyperglycemic rats with $250 \mathrm{mg} / \mathrm{kg}$ and $500 \mathrm{mg} / \mathrm{kg}$ CPP extract recovered the activities of gluconeogenic and glycolytic enzymes and also restored the liver glycogen content close to normal when compared with untreated control group of rats.

Glucose homeostasis depends on appropriate balance of glycolysis, glycogen metabolism, and gluconeogenesis [54]. The terminal step in hepatic glycogenolysis and gluconeogenesis is catalyzed by glucose-6-phosphatase and fructose1, 6-bisphosphatase. These two enzymes are involved in the production of hepatic glycogen $[55,56]$. Concentration of both of the enzymes was notably increased in alloxanized hyperglycemic rats. Results of our research study expressed considerable reduction in the activity of these enzymes which 
TABLE 4: Effect of CPP treatment on serum glucose, insulin, and glycosylated hemoglobin level in diabetic rats after 8 weeks.

\begin{tabular}{|c|c|c|c|c|}
\hline \multirow{2}{*}{ Parameters } & \multicolumn{4}{|c|}{ Groups } \\
\hline & Normal & Positive control & $250 \mathrm{mg} / \mathrm{kg} \mathrm{CPP} \mathrm{extract}$ & $500 \mathrm{mg} / \mathrm{kg}$ CPP extract \\
\hline Serum glucose $(\mathrm{mg} / \mathrm{dL})$ & $113.70 \pm 4.28 \mathrm{D}$ & $497 \pm 4.81 \mathrm{~A}$ & $218.46 \pm 2.71 \mathrm{~B}$ & $134.56 \pm 2.09 \mathrm{BC}$ \\
\hline Serum insulin $(\mathrm{mg} / \mathrm{dL})$ & $19.5 \pm 0.73 \mathrm{~A}$ & $7.37 \pm 0.93 \mathrm{D}$ & $13.54 \pm 0.58 \mathrm{BC}$ & $16.64 \pm 0.75 \mathrm{BC}$ \\
\hline HbAlc (\%) & $5.68 \pm 0.05 \mathrm{E}$ & $11.25 \pm 0.11 \mathrm{~A}$ & $8.74 \pm 0.09 \mathrm{C}$ & $67.01 \pm 0.06 \mathrm{D}$ \\
\hline
\end{tabular}

Data presented as mean \pm SE. Values not having the same letters show significant difference within a column $(P \leq 0.05)$.

TABLE 5: Effect of CPP treatment on serum leptin, amylin, and peptide YY levels in diabetic rats after 8 weeks.

\begin{tabular}{|c|c|c|c|c|}
\hline Parameters & Normal & Positive control & $\begin{array}{l}\text { Groups } \\
250 \mathrm{mg} / \mathrm{kg} \mathrm{CPP} \text { extract }\end{array}$ & $500 \mathrm{mg} / \mathrm{kg}$ CPP extract \\
\hline Serum amylin $(\mathrm{ng} / \mathrm{mL})$ & $58.3 \pm 5.82 \mathrm{C}$ & $76.5 \pm 6.21 \mathrm{~A}$ & $67.7 \pm 5.36 \mathrm{~B}$ & $61.2 \pm 5.09 \mathrm{BC}$ \\
\hline Serum leptin $(\mathrm{ng} / \mathrm{mL})$ & $0.91 \pm 0.08 \mathrm{C}$ & $2.9 \pm 0.61 \mathrm{~A}$ & $1.87 \pm 0.53 \mathrm{~B}$ & $1.22 \pm 0.47 \mathrm{BC}$ \\
\hline PYY (pg/mL) & $37 \pm 2.31 \mathrm{CD}$ & $170 \pm 4.11 \mathrm{~A}$ & $81.5 \pm 3.87 \mathrm{~B}$ & $52.7 \pm 3.21 \mathrm{BC}$ \\
\hline
\end{tabular}

Data presented as mean \pm SE. Values not having the same letters show significant difference within a column $(P \leq 0.05)$.

TABLE 6: Effect of CPP treatment on carbohydrate metabolizing enzymes and glycogen level in the liver of diabetic rats.

\begin{tabular}{lcccc}
\hline & & \multicolumn{2}{c}{ Groups } \\
Parameters & Normal & Positive control & $\begin{array}{c}250 \mathrm{mg} / \mathrm{kg} \\
\mathrm{CPP} \text { extract }\end{array}$ & $\begin{array}{c}500 \mathrm{mg} / \mathrm{kg} \\
\mathrm{CPP} \text { extract }\end{array}$ \\
\hline Hepatic hexokinase $\left(\mu \mathrm{mol}\right.$ of glucose-6-PO $\mathrm{P}_{4}$ formed/min/mg protein) & $268 \pm 11.45 \mathrm{~A}$ & $108.63 \pm 9.6 \mathrm{D}$ & $169.56 \pm 7.8 \mathrm{C}$ & $241.51 \pm 8.6 \mathrm{~B}$ \\
Gluocse-6-phosphatase $(\mu \mathrm{mol}$ of $\mathrm{Pi}$ liberated/min/mg protein) & $0.16 \pm 0.02 \mathrm{BC}$ & $0.27 \pm 0.06 \mathrm{~A}$ & $0.20 \pm 0.04 \mathrm{~B}$ & $0.17 \pm 0.43 \mathrm{BC}$ \\
Fructose 1-6-biphosphatase $(\mu \mathrm{mol}$ of $\mathrm{Pi}$ liberated/min/mg protein) & $0.65 \pm 0.07 \mathrm{BC}$ & $0.81 \pm 0.04 \mathrm{~A}$ & $0.76 \pm 0.035 \mathrm{AB}$ & $0.69 \pm 0.09 \mathrm{~B}$ \\
Glucose-6-phosphate dehydrogenase $(\mathrm{U} / \mathrm{min} / \mathrm{mg}$ protein) & $3.67 \pm 0.97 \mathrm{~A}$ & $1.54 \pm 0.45 \mathrm{BC}$ & $2.01 \pm 0.57 \mathrm{~B}$ & $3.37 \pm 0.76 \mathrm{~A}$ \\
Liver glycogen $(\mathrm{mg} / \mathrm{g}$ tissue) & $47.3 \pm 2.6 \mathrm{~A}$ & $23.5 \pm 1.97 \mathrm{BC}$ & $36.41 \pm 2.1 \mathrm{~B}$ & $42.35 \pm 1.85 \mathrm{AB}$ \\
\hline
\end{tabular}

Data presented as mean \pm SE. Values not having the same letters show significant difference within a column $(P \leq 0.05)$.

possibly is due to the restoration of insulin level after CPP treatment in treated groups 3 and 4 resulting in reduced glucose production. Pentose phosphate pathway also plays an important role in production of pentose sugars and reducing equivalent NADPH which are essential for maintenance of glucose homeostasis. Glucose-6-phosphate dehydrogenase is the key regulator of the initial step of pentose phosphate pathway, and its deficiency leads towards the production of ROS resulting in oxidative stress [57]. In alloxan-induced hyperglycemic rats, the activity of glucose-6-phosphate dehydrogenase was reduced compared to control. However, CPP extract appreciably $(P \leq 0.05)$ recovered the level of this enzyme and exerted protective effect against oxidative stress resulting in increased glucose utilization and improved lipogenesis due to the synthesis of fat from excess concentration of glucose.

3.5. Estimation of Oxidant and Antioxidant Defense Enzyme Activities. The results have summarized the effect of CPP treatment on the activity of antioxidant enzymes and lipid peroxidation level in the pancreas and liver of the control and alloxanized hyperglycemic rats. Activities of pancreatic and hepatic SOD, CAT, GR, and GPx were significantly $(P \leq 0.05)$ decreased after induction of diabetes, indicating the diminution of activities of endogenous antioxidant enzyme. However, administration of respective concentrations of CPP extract into groups 3 and 4 significantly $(P \leq 0.05)$ reinstated the antioxidant enzyme activities and considerably reduced TBARS level relative to the positive control (Tables 7 and 8). For all the biochemical parameter studied above, 8 weeks treatment of treated groups of rats with CPP (250 and $500 \mathrm{mg} / \mathrm{kg}$ ) extract showed significant $(P \leq 0.05)$ effects compared to diabetic control. Alloxan is a diabetogenic agent and responsible for the production of ROS in different tissues particularly in pancreatic tissues due to its rapid uptake by pancreas [58]. That is why intracellular ROS production was measured by using DCF-DA in the hepatic tissue in our research study. According to results, alloxan significantly $(P \leq 0.05)$ raised intracellular ROS level in hyperglycemic rats. In diabetes, upraised levels of ROS may cause glucose autooxidation, inflammation, and glycosylation of protein resulting in oxidative stress [59]. The oxidative stress induces downregulation of different genes involved in insulin secretion from the pancreas leading to hyperglycemia. However, a small amount of ROS produced under normal physiological conditions plays an important role in different biological processes [60]. Hence, the concept of oxidative stress may offer a unique therapeutic option for 
TABLE 7: Effect of CPP treatment on hepatic antioxidant enzymes levels in diabetic rats after 8 weeks.

\begin{tabular}{lcccc}
\hline Parameter & Normal & Positive control & $250 \mathrm{mg} / \mathrm{kg}$ CPP extract & $500 \mathrm{mg} / \mathrm{kg}$ CPP extract \\
\hline Catalase $\left(\mu \mathrm{mol} \mathrm{H} \mathrm{O}_{2} / \mathrm{min} / \mathrm{mg}\right.$ protein) & $53 \pm 2.03 \mathrm{~A}$ & $29.5 \pm 1.36 \mathrm{CD}$ & $36 \pm 2.05 \mathrm{BC}$ & $47.5 \pm 1.74 \mathrm{~B}$ \\
GPx (nmol/min/mg protein) & $24 \pm 1.79 \mathrm{~A}$ & $14 \pm 0.95 \mathrm{C}$ & $19 \pm 1.04 \mathrm{BC}$ & $21.5 \pm 1.34 \mathrm{AB}$ \\
$\mathrm{SOD}(\mathrm{U} / \mathrm{mg}$ proteins) & $6.3 \pm 1.09 \mathrm{~A}$ & $3.8 \pm 0.84 \mathrm{C}$ & $4.7 \pm 1.36 \mathrm{~B}$ & $5.9 \pm 1.03 \mathrm{AB}$ \\
$\mathrm{GSH}(\mathrm{mg} / \mathrm{dL}$ tissue) & $35 \pm 1.76 \mathrm{~A}$ & $24 \pm 1.2 \mathrm{C}$ & $29 \pm 1.64 \mathrm{BC}$ & $32.5 \pm 1.58 \mathrm{AB}$ \\
ROS $(\%)$ & $98 \pm 3.6 \mathrm{CD}$ & $184 \pm 4.3 \mathrm{~A}$ & $136 \pm 2.8 \mathrm{~B}$ & $107 \pm 2.3 \mathrm{C}$ \\
TBARS (nmol MDA/mg protein) & $2.77 \pm 1.1 \mathrm{BC}$ & $5.6 \pm 1.06 \mathrm{~A}$ & $4.32 .5 \pm 0.93 \mathrm{AB}$ & $3.15 \pm 0.84 \mathrm{~B}$ \\
\hline
\end{tabular}

Data presented as mean \pm SE. Values not having the same letters show significant difference within a column $(P \leq 0.05)$.

TABLE 8: Effect of CPP treatment on pancreatic antioxidant enzymes level in diabetic rats after 8 weeks.

\begin{tabular}{lcccc}
\hline Parameter & Normal & Positive control & $250 \mathrm{mg} / \mathrm{kg}$ CPP extract & $500 \mathrm{mg} / \mathrm{kg}$ CPP extract \\
\hline Catalase $(\mu \mathrm{mol} / \mathrm{min} / \mathrm{mg}$ protein) & $37 \pm 1.9 \mathrm{~A}$ & $18.45 \pm 1.02 \mathrm{C}$ & $23.5 \pm 1.27 \mathrm{~B}$ & $32.48 \pm 2.2 \mathrm{AB}$ \\
GPx (nmol/min/mg protein) & $17.5 \pm 1.5 \mathrm{~A}$ & $9.5 \pm 0.98 \mathrm{C}$ & $12.38 \pm 1.02 \mathrm{~B}$ & $15.87 \pm 1.64 \mathrm{AB}$ \\
SOD (U/mg proteins) & $4.1 \pm 0.87 \mathrm{~A}$ & $2.4 \pm 0.64 \mathrm{C}$ & $3.05 \pm 0.78 \mathrm{~B}$ & $3.8 \pm 0.84 \mathrm{AB}$ \\
GSH (mg/dL tissue) & $28.1 \pm 0.9 \mathrm{~A}$ & $16.18 \pm 1.04 \mathrm{D}$ & $19.5 \pm 0.86 \mathrm{C}$ & $24.5 \pm 1.3 \mathrm{~B}$ \\
TBARS (nmol MDA/mg protein) & $2.21 \pm 1.04 \mathrm{C}$ & $4.13 \pm 1.01 \mathrm{~A}$ & $3.52 \pm 0.87 \mathrm{~B}$ & $2.86 \pm 0.79 \mathrm{C}$ \\
\hline
\end{tabular}

Data presented as mean \pm SE. Values not having the same letters show significant difference within a column $(P \leq 0.05)$.

the management of diabetes by using nutraceuticals that possess a powerful free radical scavenging capacity and ability to boost the activity of the intracellular antioxidant system [61]. The glucose lowering potential of CPP extract is credited to strong antioxidant defense produced by polyphenols resulting in the regeneration of pancreatic cellular architecture and normal insulin production and release from $\beta$ cells.

Oxidative stress produced by the hyperglycemic state deteriorates the antioxidant defense mechanism of the body and consequently increases MDA levels and reduces the activity of antioxidant enzymes [62]. MDA, an aldehyde, is considered as a biomarker of lipid peroxidation as it is formed due to the oxidation of membrane lipids. Results had suggested that the use of CPP extract in both treated groups considerably $(P \leq 0.05)$ decreased the MDA level and raised the activities of CAT, SOD, and GPx in a dosedependent manner. Superoxide radicals are mainly responsible for the production of ROS and oxidative stress from different sources, and their dismutation by SOD is required for proper functioning of cells [63]. Glutathione, an important antioxidant, is present in excess amount in all cells. It scavenges lipid peroxides and hydrogen peroxide of GSHPx by providing an electron to form water and oxygen. This oxidized form is again converted into GSH through the action of GSH reductase. This reduced form of glutathione protects membrane lipids against the harmful effects of oxidants [49]. These results have identified improved the detoxification capability of CPP extract due to recovery of antioxidant enzymes towards normal resulting in protection of cellular organelles from oxidative stress. The antioxidant potential of CPP extract may be due to the restoration of the glycation of the antioxidant enzymes SOD, CAT, and GPx towards normal.
3.6. Histopathological Examination. According to the results, the pancreas of the control group showed normal histological features of the islets of the Langerhans cells with active nuclei and abundant cytoplasm (the endocrine portion) (Figure 2(a)). The pancreatic tissue of alloxan-induced diabetic rat demonstrated degeneration and inflammatory cellular infiltration, vacuolization, congestion, atrophy, massive necrotic changes, regression in the size of all $\beta$ cells, and pycnotic nuclei compared to control group (Figure 2(b)). These histopathological changes observed in the positive control group were like those reported previously [64]. Use of $250 \mathrm{mg} / \mathrm{kg}$ of CPP extract in alloxanized hyperglycemic rats produced marked improvement in cellular injuries as evident from partial restoration of islets and $\beta$ cells mass (Figure 2(c)). These results showed considerable improvement in the population of $\beta$ cells and reduction in tissue necrosis. The response of the highest dose-treated group $(500 \mathrm{mg} / \mathrm{kg}$ ) exhibited an increased dense volume of islet cells with a reduced number of necrotic $\beta$ cells which is a sign of regeneration (Figure $2(\mathrm{~d})$ ). According to the results, administration of $500 \mathrm{mg} / \mathrm{kg}$ CPP in hyperglycemic rats showed healthy architecture of islets of Langerhans with active $\beta$ cells and absence of any necrotic change. These results are in agreement with a study in which treatment of diabetic rats with Aloe vera extracts resulted in significant increase in the number of islets of Langerhans and improvement in insulin secretion [65].

\subsection{Effect of CPP Extract on Pancreatic and Hepatic Genes}

3.7.1. CPP Extract Ameliorates Traf-4, Traf-6, and MAPK-8 over Expression in Diabetic Rats. The MAPK downstream JNK signaling pathway has been widely confirmed to play 


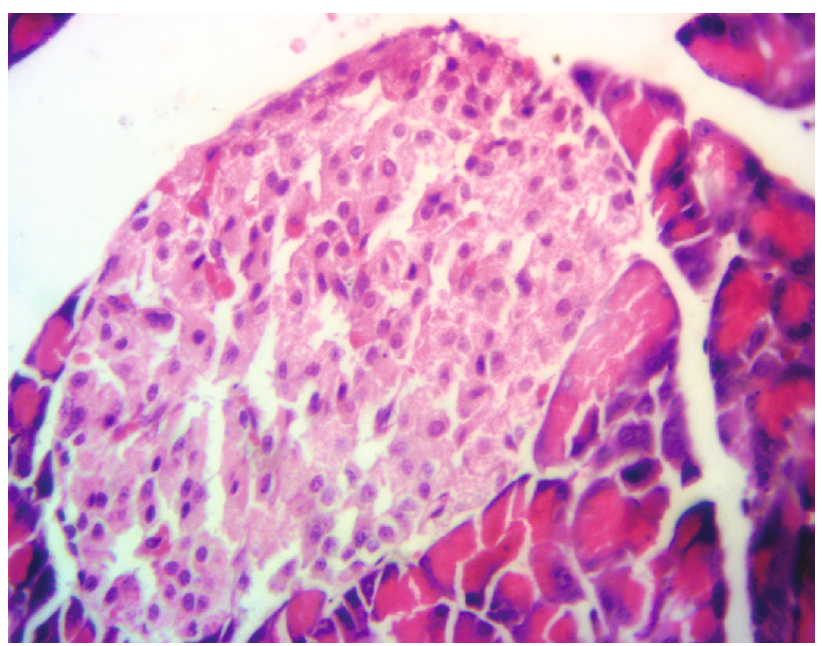

(a)

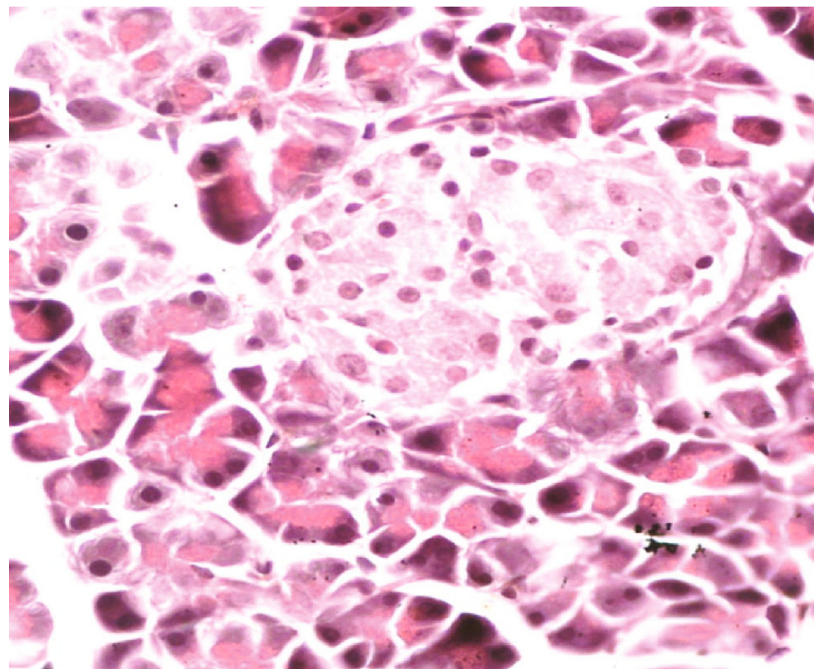

(c)

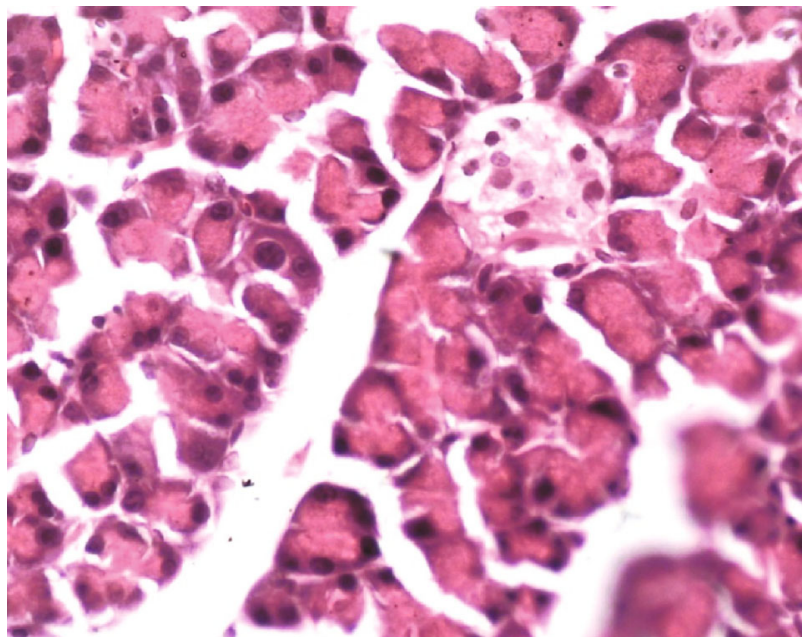

(b)

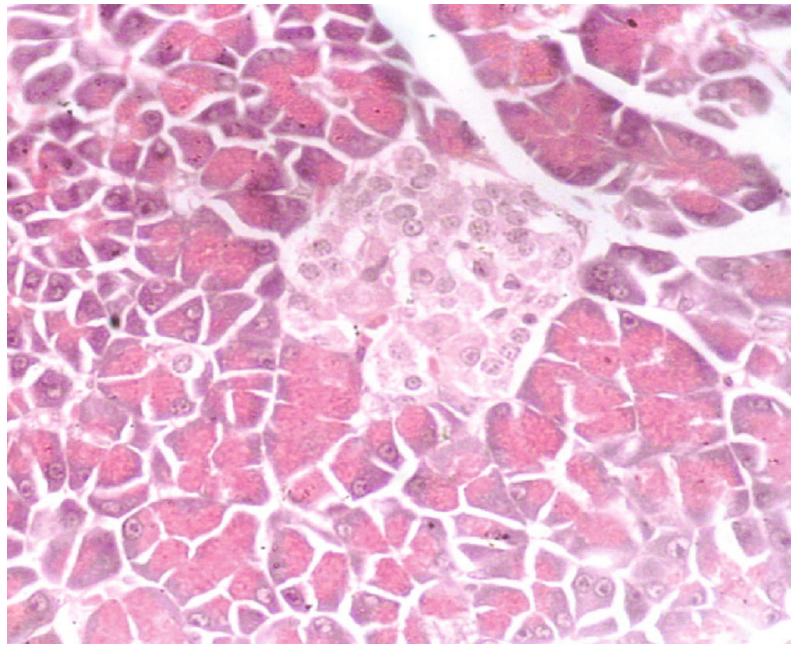

(d)

Figure 2: (a) Pancreatic section of the control group showed normal histological features of beta cells and islets of Langerhans. (b) Pancreatic section of the diabetic/positive control group showed degenerative and necrotic changes in the islet of the Langerhans cells, congestion, and loss of cellular content. There was atrophy and regression in the size of all of the islets of the Langerhans cells. (c, d) The responses of the treated groups ( 250 and $500 \mathrm{mg} / \mathrm{kg} \mathrm{CPP}$ extract) showed active beta cells and increased dense volume of the islet cell which is a sign of regeneration.

important roles in the pathological process of diabetes. In the diabetic rats, Traf- 4 and Traf- 6 expressions were upregulated in response to a high level of ROS production, which significantly $(P \leq 0.01)$ differed from the normal group. Oral CPP administration $(250 \mathrm{mg} / \mathrm{kg})$ resulted in marked decline in the ROS level resulting in decreased expressions of Traf-4 and Traf- 6 in the diabetic rats $(P \leq 0.01)$ which closely approximated the healthy controls. As shown in Figure 3, ROS-dependent activation of Traf- 4 and Traf- 6 resulted in upregulation $(P \leq 0.01)$ of MAPK-8 gene in diabetic groups relative to normal or untreated group of rats. After administration of different concentrations of CPP extract into groups 3 and 4, the phosphorylation level of MAPK-8/JNK1 was significantly decreased in different degrees. Among the data, treatment with $500 \mathrm{mg} / \mathrm{kg}$ remarkably $(P \leq 0.01)$ resisted the activation of JNK pathway resulting in significant
$(P \leq 0.01)$ reduction of apoptosis of pancreatic $\beta$ cells induced by hyperglycemia.

It has been well demonstrated that the oxidative stressinduced MAPK downstream JNK pathway plays a crucial role in the development of diabetes [66]. The JNK proteins are activated by a series of phosphorylation on threonine and tyrosine residues via MKK4 and MKK7 in response to various stress stimuli like environmental stresses and inflammatory cytokines [67]. Oxidative stress stimulates both TNFreceptor-associated factors 4 and 6 (TRAF- 4 ) and (TRAF- 6 ) for the activation of ASK1 and the subsequent activation of downstream JNK signaling in various tissues, including pancreatic islets $[68,69]$. Upon activation, the phosphorylated JNK phosphorylates c-Jun in the nucleus as it is translocated into the nucleus upon activation. Phosphorylated c-Jun leads towards the formation of activated protein-1 (AP-1). The 


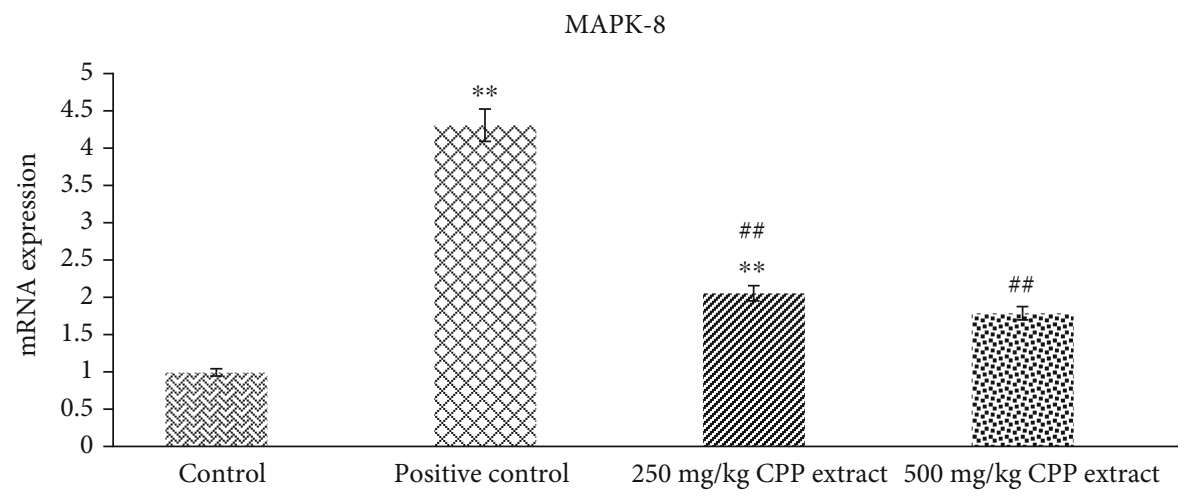

(a)

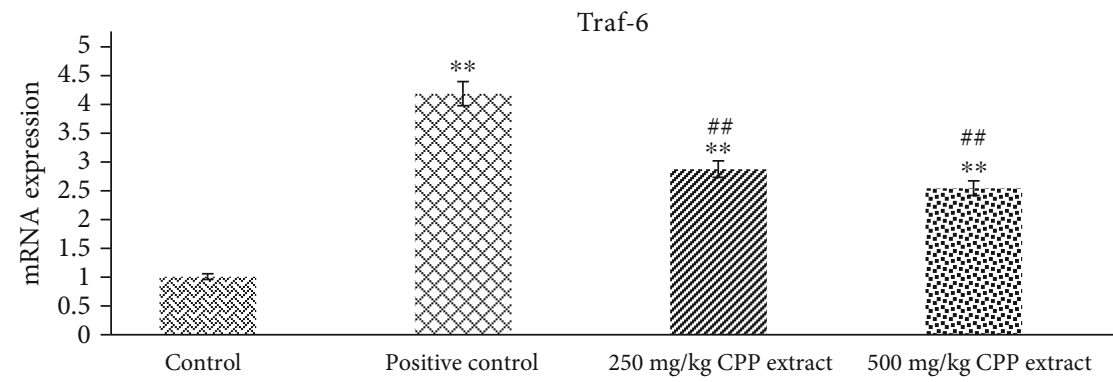

(b)

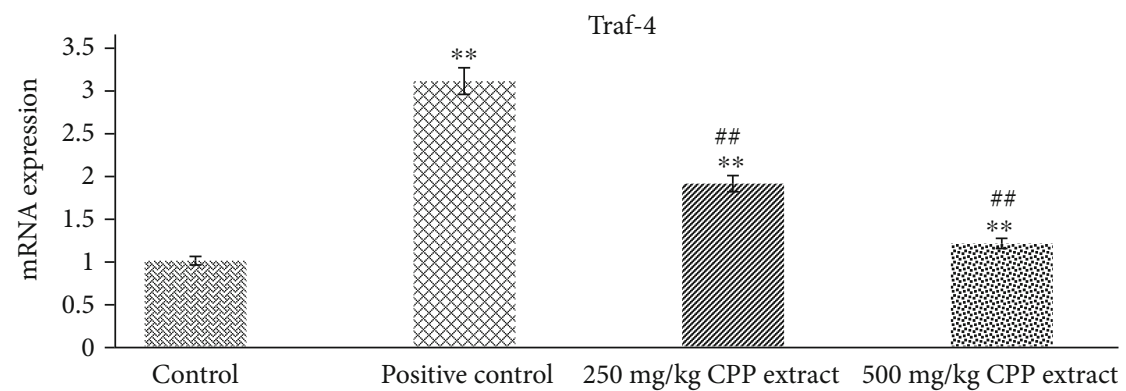

(c)

FIGURE 3: Rat's pancreatic gene expression profile: mRNA expression of (a) MAPK-8, (b) Traf-6, and (c) Traf-4 in control, positive control, $250 \mathrm{mg} / \mathrm{kg}$, and $500 \mathrm{mg} / \mathrm{kg}$ CPP-treated groups. ${ }^{* *} P \leq 0.01$ shows significant difference between control and other groups. ${ }^{\# \#} P \leq 0.01$ indicates significant difference between positive control and CPP-treated groups.

JNK-AP-1 pathway is reported to upregulate the expression of different proapoptotic genes involved in JNK-induced apoptosis [70].

A positive feedback effect may exist between ROS and JNK, in which increase in ROS level enhanced the expression of genes involved in JNK pathway, and activated JNK promotes the production of more ROS [71]. MapK-8, also known as Jnk-1 (c-Jun N-terminal protein kinase 1), is critically involved in the generation of oxidative stress resulting in the induction of subsequent events of stress-induced apoptosis. Furthermore, activation of Jnk-1 gene leads towards inflammation of islets of Langerhans, pancreatic $\beta$ cells dysfunction, and release of insufficient or defective insulin from $\beta$ cells [72]. Under diabetic conditions, the JNK pathway is stimulated in many tissues, and this activation results in insulin resistance. However, inhibition of this pathway in different research trials also resulted in the reduction of insulin resistance and on the whole diabetes [73].
In the present research study, the purpose of evaluating the expression of TRAF-4, TRAF-6, and Jnk1/MapK8 in diabetic and control rats after CPP treatment was to study how polyphenolics improve conditions in the presence of diabetes. According to the results, expression levels of TRAF-4, TRAF-6, and MAPK-8 genes were drastically raised in hyperglycemic rats. However, CPP treatment considerably $(P \leq 0.01)$ inhibited the activation of JNK pathway induced by high glucose. Taken together, we found that CPP extract reversed the upregulation of TRAF-4 and TRAF- 6 resulting in the inhibition of MAPK-8 expression. In conclusion, the present research study has confirmed the antioxidant, antihyperglycemic, and regenerative potential of CPP extract due to the significant reduction in oxidative stress, downregulation of JNK/c-Jun signaling pathway, and increase in the regeneration of pancreatic $\beta$ cells after 8 weeks CPP treatment of alloxan-induced diabetic rats. 


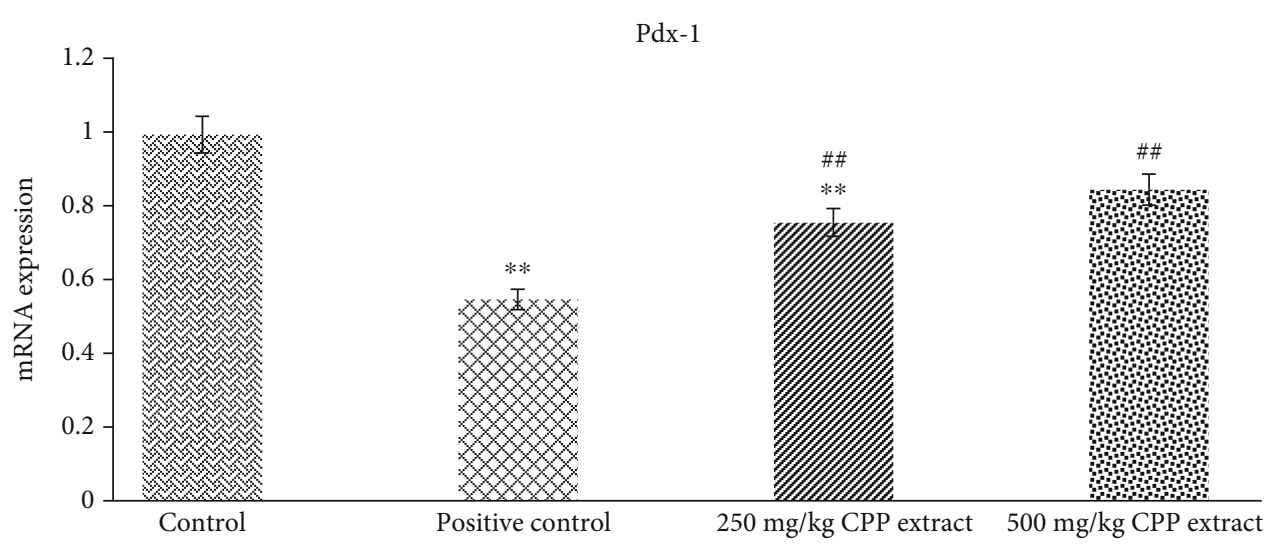

(a)

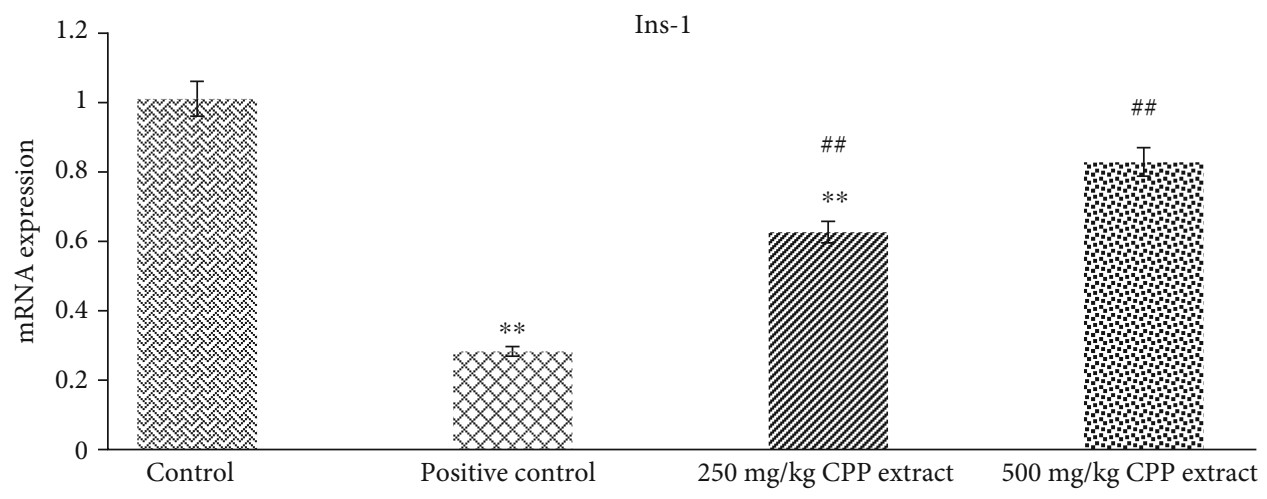

(b)

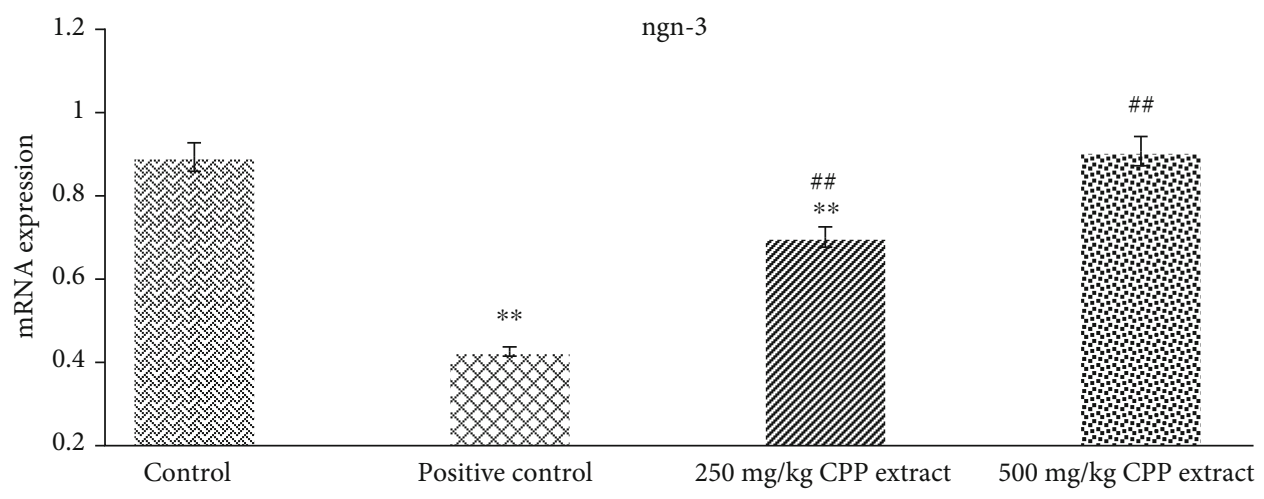

(c)

Figure 4: Rat's pancreatic gene expression profile: mRNA expression of (a) Pdx-1, (b) Ins-1, and (c) Ngn-3 in control, positive control, $250 \mathrm{mg} / \mathrm{kg}$, and $500 \mathrm{mg} / \mathrm{kg}$ CPP-treated groups. ${ }^{* *} P \leq 0.01$ shows significant difference between control and other groups. ${ }^{\# \#} P \leq 0.01$ indicates significant difference between positive control and CPP-treated groups.

3.7.2. Effects of CPP Extract on Ins-1, ngn-3, and Pdx-1 Expression in Diabetic Rats. In order to identify the potential mechanism adopted by CPP extract in the regeneration of $\beta$ cells and improved insulin production, the effect of CPP on insulin signaling pathway through the expression of genes (Ins-1, ngn-3, Pdx-1, IRS-1, and Glut-4) was investigated by the RT-PCR analysis. Expression levels of Ins-1, ngn-3, and $P d x-1$ in pancreatic tissues were appreciably $(P \leq 0.01)$ downregulated in the diabetic rats compared with the normal group. The results have explored that CPP extract significantly $(P \leq 0.01)$ increased Ins- $1, P d x-1$, and ngn-3 protein expression resulting in the regeneration of $\beta$ cells of pancreas (Figure 4).

3.7.3. Effects of CPP Extract Treatment on IRS-1 and Glut-4 Genes Level in Target Rats. To investigate the mechanisms of CPP extract on insulin signaling pathway, expression levels of different genes including IRS-1 and Glut-4 were investigated. The transcription levels of IRS-1 and Glut-4 genes were examined in the liver samples of control, diabetic, and CPP-treated groups. According to the results, IRS-1 and Glut-4 gene expression was significantly $(P \leq 0.01)$ reduced 


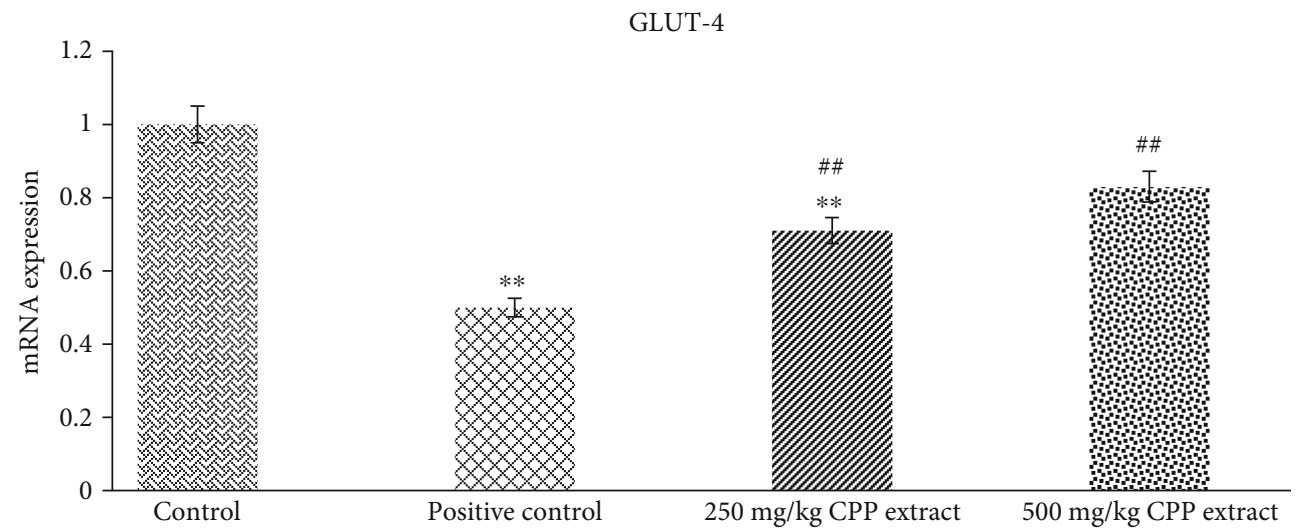

(a)

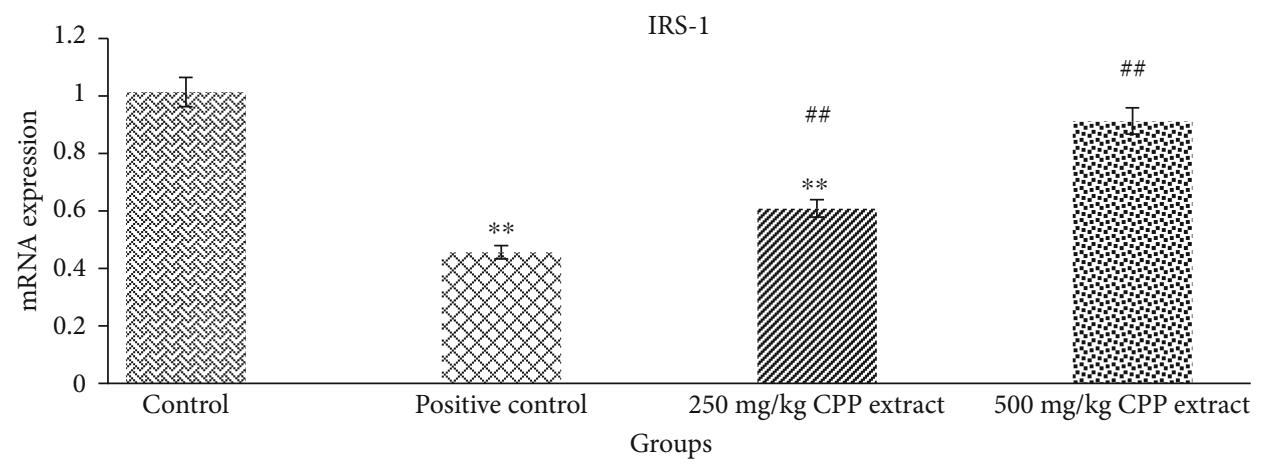

(b)

FIGURE 5: Rat's hepatic gene expression profile: mRNA expression of (a) GLUT-4 and (b) IRS-1 in control, positive control, $250 \mathrm{mg} / \mathrm{kg}$, and $500 \mathrm{mg} / \mathrm{kg}$ CPP-treated groups. ${ }^{* *} P \leq 0.01$ shows significant difference between control and other groups. ${ }^{\# \#} P \leq 0.01$ indicates significant difference between positive control and CPP-treated groups.

in the positive control group of rats. However, oral administration of CPP extract $(250 \mathrm{mg} / \mathrm{kg}$ and $500 \mathrm{mg} / \mathrm{kg})$ in treated groups 3 and 4 of rats considerably $(P \leq 0.01)$ increased the levels of IRS- 1 compared with the model group. In addition, CPP treatment also significantly $(P \leq 0.01)$ promoted GLUT4 protein expression resulting in the improvement of insulin resistance compared to positive control group (Figure 5).

As shown in Figures 4 and 5, all genes were downregulated in diabetic rats. After CPP treatment, gene expression levels were significantly $(P \leq 0.01)$ restored towards normal, which indicates improvement in $\beta$ cells efficiency and alleviation of insulin resistance in all insulin-affected tissues. Activation of JNK pathway leads to phosphorylation of serine residue at particular sites in insulin receptor substrate-1 (IRS-1), which decreases the potential of IRS-1 to transfer the signals [74]. The delivery of insulin signals begins with phosphorylation of tyrosine residue at insulin receptor and its substrate [75]. The CPP extract could increase IRS-1 protein phosphorylation, activate PI3K/AKT pathway, stimulate GLUT-4 translocation to the cell membrane, and enhance glucose transport and lipid metabolism [76, 77].

The pancreatic and duodenal homeobox $1(\mathrm{Pdx}-1)$ is an important gene involved in the development and functioning of $\beta$ cells [72]. Similar to MafA, it is regarded as a key controller and regulator of glucose-stimulated insulin gene (Ins-1) transcription. The neurogenin-3 (ngn-3) is important in the central nervous system development and cell differentiation of pancreatic $\beta$ cells [78]. Both of these transcription factors, ngn-3 and Pdx-1, are markers of endocrine cell precursors. Beta cell damage caused by either oxidative stress or glucotoxicity downregulates the expression of Pdx-1, and downregulation of $\mathrm{Pdx}-1$ significantly $(P \leq 0.01)$ reduces insulin production favoring induction of diabetes. Moreover, downregulation of ngn-3 at embryonic stages results in undifferentiated endocrine part of the pancreas [79]. Indeed, in our research study, activation of JNK pathway in diabetic rats drastically inhibited expression of ngn-3 and nuclear localization of Pdx-1 and its DNA binding capability resulting in impaired insulin gene (Ins-1) expression. Administration of $250 \mathrm{mg} / \mathrm{kg}$ and 500 of CPP extract in treated groups of rats appreciably $(P \leq 0.01)$ improved the $P d x-1$ and ngn-3 gene expressions resulting in the regeneration of $\beta$ cells and increased insulin release from $\beta$ cells.

\section{Conclusion}

The present study suggests that CPP confers antihyperglycemic effect on alloxanized diabetic rats by reducing oxidative stress and downregulating the expression of different genes involved in JNK pathway. The CPP extract has also ameliorated diabetes-induced pancreatic $\beta$ cells loss by repairing the antioxidant defense mechanism and restoring insulin, 
amylin, leptin, and carbohydrate-metabolizing enzyme levels. Moreover, CPP treatment has protective effects on the structure and function of $\beta$ cells which may be accompanied by the upregulation of genes involved in insulin signaling pathway.

\section{Data Availability}

The data used to support the results of present research work are accessible and can be obtained from the corresponding author on demand.

\section{Conflicts of Interest}

The authors declare no conflict of interest.

\section{Authors' Contributions}

All authors contribute equally in the preparation of manuscript.

\section{Acknowledgments}

We acknowledge the financial support from the National Research Project for Universities (NRPU) Project No. 6347 funded by the Higher Education Commission (HEC), Pakistan.

\section{References}

[1] T. Seuring, O. Archangelidi, and M. Suhrcke, "The economic costs of type 2 diabetes: a global systematic review," PharmacoEconomics, vol. 33, no. 8, pp. 811-831, 2015.

[2] S. W. Choi and C. K. Ho, "Antioxidant properties of drugs used in type 2 diabetes management: could they contribute to, confound or conceal effects of antioxidant therapy?," Redox Report, vol. 23, no. 1, pp. 1-24, 2018.

[3] R. J. Perry, L. Peng, G. W. Cline et al., "Mechanisms by which a Very-Low-Calorie Diet Reverses Hyperglycemia in a Rat Model of Type 2 Diabetes," Cell Metabolism, vol. 27, no. 1, pp. 210-217.e3, 2018.

[4] M. Alsharidah, M. Algeffari, A. M. H. Abdel-Moneim, M. F. Lutfi, and H. Alshelowi, "Effect of combined gliclazide/metformin treatment on oxidative stress, lipid profile, and hepatorenal functions in type 2 diabetic patients," Saudi Pharmaceutical Journal, vol. 26, no. 1, pp. 1-6, 2018.

[5] R. Khan, A. Q. Khan, W. Qamar et al., "Chrysin protects against cisplatin-induced colon. toxicity via amelioration of oxidative stress and apoptosis: Probable role of p38MAPK and p53," Toxicology and Applied Pharmacology, vol. 258, no. 3, pp. 315-329, 2012.

[6] R. G. Sathiyabama, G. Rajiv Gandhi, M. Denadai et al., "Evidence of insulin-dependent signalling mechanisms produced by Citrus sinensis (L.) Osbeck fruit peel in an insulin resistant diabetic animal model," Food and Chemical Toxicology, vol. 116, Part B, pp. 86-99, 2018.

[7] A. M. Pisoschi and A. Pop, "The role of antioxidants in the chemistry of oxidative stress: a review," European Journal of Medicinal Chemistry, vol. 97, pp. 55-74, 2015.

[8] X. J. Yang, B. Dang, and M. T. Fan, "Free and bound phenolic compound content and antioxidant activity of different culti- vated blue highland barley varieties from the Qinghai-Tibet Plateau," Molecules, vol. 23, no. 4, p. 879, 2018.

[9] C. M. O. Volpe, P. H. Villar-Delfino, P. M. F. Dos Anjos, and J. A. Nogueira-Machado, "Cellular death, reactive oxygen species (ROS) and diabetic complications," Cell Death \& Disease, vol. 9, no. 2, p. 119, 2018.

[10] H. Taha, A. Arya, A. K. Khan, N. Shahid, M. I. Bin Noordin, and S. Mohan, "Effect of Pseuduvaria macrophylla in attenuating hyperglycemia mediated oxidative stress and inflammatory response in STZ-nicotinamide induced diabetic rats by upregulating insulin secretion and glucose transporter-1, 2 and 4 proteins expression," Journal of Applied Biomedicine, vol. 16, no. 4, pp. 263-273, 2018.

[11] D. J. Newman and G. M. Cragg, "Natural products as sources of new drugs from 1981 to 2014," Journal of Natural Products, vol. 79, no. 3, pp. 629-661, 2016.

[12] L. Liu, D. Tang, H. Zhao, X. Xin, and H. A. Aisa, "Hypoglycemic effect of the polyphenols rich extract from Rose rugosa Thunb on high fat diet and STZ induced diabetic rats," Journal of Ethnopharmacology, vol. 200, pp. 174-181, 2017.

[13] A. C. de Camargo, M. A. B. Regitano-d'Arce, A. C. T. Biasoto, and F. Shahidi, "Low molecular weight phenolics of grape juice and winemaking byproducts: antioxidant activities and inhibition of oxidation of human lowdensity lipoprotein cholesterol and DNA strand breakage," Journal of Agricultural and Food Chemistry, vol. 62, no. 50, pp. 12159-12171, 2014.

[14] J. L. Rios, F. Francini, and G. R. Schinella, "Natural products for the treatment of type diabetes mellitus," Planta Medica, vol. 81, no. 12-13, pp. 975-994, 2015.

[15] R. Vieira, S. B. Souto, E. Sánchez-López et al., "Sugar-lowering drugs for type 2 diabetes mellitus and metabolic syndrome-review of classical and new compounds: part-I," Pharmaceuticals, vol. 12, no. 4, p. 152, 2019.

[16] V. Sekar, S. Mani, R. Malarvizhi, P. Nithya, and H. R. Vasanthi, "Antidiabetic effect of mangiferin in combination with oral hypoglycemic agents metformin and gliclazide," Phytomedicine, vol. 59, article 152901, 2019.

[17] L. F. Gushiken, F. P. Beserra, A. L. Rozza, P. L. Bérgamo, D. A. Bérgamo, and C. H. Pellizzon, "Chemical and biological aspects of extracts from medicinal plants with antidiabetic effects," The Review of Diabetic Studies, vol. 13, no. 2-3, pp. 96-112, 2016.

[18] V. Subbiah, P. Nagaraja, P. Narayan, and H. G. R. Nagendra, "Evaluation of pharmacological properties of Caesalpinia bonducella seed and shell extract," The Pharmacogenomics Journal, vol. 11, no. 1, pp. 150-154, 2019.

[19] N. R. Kakade, S. S. Pingale, and M. G. Chaskar, "Phytochemical and pharmacological review of Caesalpinia bonducella," International Research Journal of Pharmacy, vol. 12, pp. 1217, 2016.

[20] E. N. Sembiring, B. Elya, and R. Sauriasari, "Phytochemical screening, total flavonoid and total phenolic content and antioxidant activity of different parts of Caesalpinia bonduc (L.) Roxb," Pharmacognosy Journal, vol. 10, no. 1, pp. 123-127, 2017.

[21] M. C. Sabu, K. Smitha, and R. Kuttan, "Anti-diabetic activity of green tea polyphenols and their role in reducing oxidative stress in experimental diabetes," Journal of Ethnopharmacology, vol. 83, no. 1-2, pp. 109-116, 2002.

[22] D. Moonmun, R. Majumder, and A. Lopamudra, "Quantitative phytochemical estimation and evaluation of antioxidant 
and antibacterial activity of methanol and ethanol extracts of Heliconia rostrata," Indian Journal of Pharmaceutical Sciences, vol. 79, pp. 79-90, 2017.

[23] J. K. S. Andrade, M. Denadai, C. S. de Oliveira, M. L. Nunes, and N. Narain, "Evaluation of bioactive compounds potential and antioxidant activity of brown, green and red propolis from Brazilian northeast region," Food Research International, vol. 101, pp. 129-138, 2017.

[24] O. H. Lowry, N. J. Rosebrough, A. L. Farr, and R. J. Randall, "Protein measurement with the Folin phenol reagent," The Journal of Biological Chemistry, vol. 193, no. 1, pp. 265-275, 1951.

[25] D. T. Plummer, Practical Biochemistry, McGraw Hill Book Comp, England, 3rd edition, 1971.

[26] K. Rashid, S. Bhattacharya, and P. C. Sil, "Protective role of Dsaccharic acid-1, 4- lactone in alloxan induced oxidative stress in the spleen tissue of diabetic rats is mediated by suppressing mitochondria dependent apoptotic pathway," Free Radical Research, vol. 46, no. 3, pp. 240-252, 2012.

[27] H. Ohkawa, N. Ohishi, and K. Yagi, “Assay for lipid peroxides in animal tissues by thiobarbituric acid reaction," Analytical Biochemistry, vol. 95, no. 2, pp. 351-358, 1979.

[28] H. P. Misra and I. Fridovich, "The role of superoxide anion in the auto oxidation of epinephrine and a simple assay of superoxide dismutase," The Journal of Biological Chemistry, vol. 247, no. 10, pp. 3170-3175, 1972.

[29] H. Eslami, R. A. Batavani, S. Asr I-Rezaei, and R. Hobbenaghi, "Changes of stress oxidative enzymes in rat mammary tissue, blood and milk after experimental mastitis induced by E. coli lipopolysaccharide," Veterinary Research Forum, vol. 6, no. 2, pp. 131-136, 2015.

[30] S. Takahara, H. B. Hamilton, J. V. Neel, T. Y. Kobara, Y. Ogura, and E. T. Nishimura, "Hypocatalasemia, a new genetic carrier state," Journal of Clinical Investigation, vol. 39, no. 4, pp. 610-619, 1960.

[31] J. T. Rotruck, A. L. Pope, H. E. Ganther, A. B. Swanson, D. G. Hafeman, and W. G. Hoekstra, "Selenium; biochemical role as a component of glutathione peroxidase," Science, vol. 179, no. 4073 , pp. $588-590,1973$.

[32] G. L. Ellman, "Tissue sulfhydryl groups," Archives of Biochemistry and Biophysics, vol. 82, no. 1, pp. 70-77, 1959.

[33] J. D. Bancroft and M. Gamble, Theory and Practice of Histological Techniques, Elsevier, 2007.

[34] J. L. Liu and Y. C. Patel, "Glucocorticoids inhibit somatostatin gene expression through accelerated degradation of somatostatin messenger ribonucleic acid in human thyroid medullary carcinoma (TT) cells," Endocrinology, vol. 136, no. 6, pp. 2389-2396, 1995.

[35] A. Iftikhar, B. Aslam, F. Muhammad, and T. Khaliq, "Polyherbal formulation Ameliorates diabetes mellitus in alloxan-induced diabetic rats: involvement of pancreatic genes expression," Pakistan Veterinary Journal, vol. 38, no. 3, pp. 261-265, 2018.

[36] I. Kade, Y. Ogunbolude, J. Kamdem, and J. Rocha, "Influence of gallic acid on oxidative stress-linked streptozotocininduced pancreatic dysfunction in diabetic rats," Journal of Basic and Clinical Physiology and Pharmacology, vol. 25, no. 1, pp. 35-45, 2014.

[37] N. Kahkeshani, F. Farzaei, M. Fotouhi et al., "Pharmacological effects of gallic acid in health and disease: a mechanistic review," Iranian Journal of Basic Medical Sciences, vol. 22, no. 3, pp. 225-237, 2019.
[38] M. Matboli, S. Eissa, D. Ibrahim, M. G. A. Hegazy, S. S. Imam, and E. K. Habib, "Caffeic acid attenuates diabetic kidney disease via modulation of autophagy in a high-fat diet/streptozotocin-induced diabetic rat," Scientific Reports, vol. 7, no. 1, p. 2263, 2017.

[39] P. S. M. Prince and A. J. Roy, “ $p$-Coumaric acid attenuates apoptosis in isoproterenol-induced myocardial infarcted rats by inhibiting oxidative stress," International Journal of Cardiology, vol. 168, no. 4, pp. 3259-3266, 2013.

[40] A. Narasimhan, M. Chinnaiyan, and B. Karundevi, "Ferulic acid exerts its antidiabetic effect by modulating insulinsignalling molecules in the liver of high-fat diet and fructose-induced type-2 diabetic adult male rat," Applied Physiology, Nutrition, and Metabolism, vol. 40, no. 8, pp. 769-781, 2015.

[41] Y. Ito, M. Fukui, M. Kanda et al., "Therapeutic effects of the allosteric protein tyrosine phosphatase $1 \mathrm{~B}$ inhibitor KY-226 on experimental diabetes and obesity via enhancements in insulin and leptin signaling in mice," Journal of Pharmacological Sciences, vol. 137, no. 1, pp. 38-46, 2018.

[42] J. N. Flak and M. G. Myers Jr., "Minireview: CNS mechanisms of leptin action," Molecular Endocrinology, vol. 30, no. 1, pp. 3-12, 2016.

[43] W. Zeng, R. M. Pirzgalska, M. M. Pereira et al., "Sympathetic neuro-adipose connections mediate leptin-driven lipolysis," Cell, vol. 163, no. 1, pp. 84-94, 2015.

[44] R. C. Tsou, K. S. Rak, D. J. Zimmer, and K. K. Bence, "Improved metabolic phenotype of hypothalamic PTP1Bdeficiency is dependent upon the leptin receptor," Molecular Metabolism, vol. 3, no. 3, pp. 301-312, 2014.

[45] I. Osegbe, H. Okpara, and E. Azinge, "Relationship between serum leptin and insulin resistance among obese Nigerian women," Annals of African Medicine, vol. 15, no. 1, pp. 1419, 2016.

[46] A. Ardid-Ruiz, M. Ibars, P. Mena et al., "Potential involvement of peripheral leptin/STAT3 signaling in the effects of resveratrol and its metabolites on reducing body fat accumulation," Nutrients, vol. 10, no. 11, p. 1757, 2018.

[47] Q. Sun, R. M. van Dam, J. B. Meigs, O. H. Franco, C. S. Mantzoros, and F. B. Hu, "Leptin and soluble leptin receptor levels in plasma and risk of type 2 diabetes in U.S. women: a prospective study," Diabetes, vol. 59, no. 3, pp. 611-618, 2010.

[48] S. Bahramikia and R. Yazdanparast, "Inhibition of human islet amyloid polypeptide or amylin aggregation by two manganese-salen derivatives," European Journal of Pharmacology, vol. 707, no. 1-3, pp. 17-25, 2013.

[49] S. Nurdiana, Y. M. Goh, H. Ahmad et al., "Changes in pancreatic histology, insulin secretion and oxidative status in diabetic rats following treatment with Ficus deltoidea and vitexin," BMC Complementary and Alternative Medicine, vol. 17, no. 1, p. 290, 2017.

[50] N. Shigihara, A. Fukunaka, A. Hara et al., "Human IAPPinduced pancreatic $\beta$ cell toxicity and its regulation by autophagy," The Journal of Clinical Investigation, vol. 124, no. 8, pp. 3634-3644, 2014.

[51] J. A. Olsen, L. A. Kenna, M. G. Spelios, M. J. Hessner, and E. M. Akirav, "Circulating differentially methylated amylin DNA as a biomarker of $\beta$-cell loss in type 1 diabetes," PLoS One, vol. 11, no. 4, article e0152662, 2016.

[52] A. L. Fuentes, K. Hennessy, J. Pascual et al., "Identification of plant extracts that inhibit the formation of diabetes-linked 
IAPP amyloid," Journal of Herbal Medicine, vol. 6, no. 1, pp. 37-41, 2016.

[53] A. Pithadia, J. R. Brender, C. A. Fierke, and A. Ramamoorthy, "Inhibition of IAPP Aggregation and Toxicity by Natural Products and Derivatives," Journal Diabetes Research, vol. 2016, article 2046327, 12 pages, 2016.

[54] S. Q. Zhang, X. H. Ma, L. Zhang, H. Sun, and X. Liu, "Capsaicin reduces blood glucose by increasing insulin levels and glycogen content better than capsiate in streptozotocin-induced diabetic rats," Journal of Agricultural and Food Chemistry, vol. 65, no. 11, pp. 2323-2330, 2017.

[55] R. Ramu, P. S. Shirahatti, S. Nayakavadi et al., "The effect of a plant extract enriched in stigmasterol and $\beta$-sitosterol on glycaemic status and glucose metabolism in alloxan-induced diabetic rats," Food \& Function, vol. 7, no. 9, pp. 3999-4011, 2016.

[56] X. Lin, H. Shi, Y. Cui et al., "Dendrobium mixture regulates hepatic gluconeogenesis in diabetic rats via the phosphoinositide-3-kinase/protein kinase B signaling pathway," Experimental and Therapeutic Medicine, vol. 16, pp. 204-212, 2018.

[57] C. Njume, O. Donkor, and A. J. McAinch, "Predisposing factors of type 2 diabetes mellitus and the potential protective role of native plants with functional properties," Journal of Functional Foods, vol. 53, pp. 115-124, 2019.

[58] B. Ahmad, M. U. Rehman, I. Amin et al., "Zingerone (4-(4hydroxy-3-methylphenyl) butan-2-one) protects against alloxan- induced diabetes via alleviation of oxidative stress and inflammation: Probable role of NF-kB activation," Saudi Pharmaceutical Journal, vol. 26, no. 8, pp. 1137-1145, 2018.

[59] K. E. Petersen, J. Lykkesfeldt, K. Raun, and G. Rakipovski, "Brief communication: plasma lipid oxidation predicts atherosclerotic status better than cholesterol in diabetic apolipoprotein E deficient mice," Experimental Biology and Medicine, vol. 242, no. 1, pp. 88-91, 2016.

[60] H. Zhang, J. Birch, J. Pei et al., "Identification of six phytochemical compounds from Asparagus officinalis L. root cultivars from New Zealand and China using UAE-SPE-UPLCMS/MS: effects of extracts on $\mathrm{H}_{2} \mathrm{O}_{2}$-induced oxidative stress," Nutrients, vol. 11, no. 1, p. 107, 2019.

[61] G. D. Noratto, N. N. Lage, B. P. Chew, S. U. Mertens-Talcott, S. T. Talcott, and M. Pedrosa, "Non-anthocyanin phenolics in cherry (Prunus avium L.) modulate IL-6, liver lipids and expression of PPAR $\delta$ and LXRs in obese diabetic $(\mathrm{db} / \mathrm{db})$ mice," Food Chemistry, vol. 266, pp. 405-414, 2018.

[62] J. Wang and H. Wang, "Oxidative stress in pancreatic beta cell regeneration," Oxidative Medicine and Cellular Longevity, vol. 2017, Article ID 1930261, 9 pages, 2017.

[63] R. D. Vellai, S. Chandiran, and S. S. Pillai, "GTF-231, a mixture of gymnemic acid, trigonelline and ferulic acid significantly ameliorates oxidative stress in experimental type 2 diabetes in rats," Canadian Journal of Diabetes, vol. 42, no. 3, pp. 237-244, 2018.

[64] S. M. A. Sangi, M. I. Sulaiman, M. F. A. el-wahab, E. I. Ahmedani, and S. S. Ali, "Antihyperglycemic effect of thymoquinone and oleuropein, on streptozotocin-induced diabetes mellitus in experimental animals," Pharmacognosy Magazine, vol. 11, no. 44, pp. 251-257, 2015.

[65] A. Noor, S. Gunasekaran, and M. A. Vijayalakshmi, "Improvement of insulin secretion and pancreatic $\beta$-cell function in streptozotocin-induced diabetic rats treated with Aloe vera extract," Pharmacognosy Research, vol. 9, no. 5, pp. 99-S104, 2017.
[66] K. M. A. Hassanin, M. O. Mahmoud, H. M. Hassan, A. H. Abdel-Razik, L. N. Aziz, and M. E. Rateb, "Balanites aegyptiaca ameliorates insulin secretion and decreases pancreatic apoptosis in diabetic rats: Role of SAPK/JNK pathway," Biomedicine \& Pharmacotherapy, vol. 102, pp. 1084-1091, 2018.

[67] A. Kumar, U. K. Singh, S. G. Kini et al., "JNK pathway signaling: a novel and smarter therapeutic targets for various biological diseases," Future Medicinal Chemistry, vol. 7, no. 15, pp. 2065-2086, 2015.

[68] J. H. Shi and S. C. Sun, "Tumor necrosis factor receptorassociated factor regulation of nuclear factor $\kappa \mathrm{B}$ and mitogen-activated protein kinase pathways," Frontiers in Immunology, vol. 9, p. 1849, 2018.

[69] A. I. Lalani, S. Zhu, S. Gokhale, J. Jin, and P. Xie, "TRAF molecules in inflammation and inflammatory diseases," Current Pharmacology Reports, vol. 4, no. 1, pp. 64-90, 2018.

[70] H. Li, H. Y. Luo, Q. Liu et al., "Intermittent high glucose exacerbates A-FABP activation and inflammatory response through TLR4-JNK signaling in THP-1 cells," Journal of Immunology Research, vol. 2018, Article ID 1319272, 9 pages, 2018.

[71] J. Luo, Y. Xiang, X. Xu et al., "High glucose-induced ROS production stimulates proliferation of pancreatic cancer via inactivating the JNK pathway," Oxidative Medicine and Cellular Longevity, vol. 2018, Article ID 6917206, 10 pages, 2018.

[72] W. Gao, X. Du, L. Lei et al., "NEFA-induced ROS impaired insulin signalling through the JNK and p38MAPK pathways in non-alcoholic steatohepatitis," Journal of Cellular and Molecular Medicine, vol. 22, no. 7, pp. 3408-3422, 2018.

[73] J. Yan, C. Wang, Y. Jin et al., "Catalpol ameliorates hepatic insulin resistance in type 2 diabetes through acting on AMPK/NOX4/PI3K/AKT pathway," Pharmacological Research, vol. 130, pp. 466-480, 2018.

[74] J. Guo, J. Wang, S. Song et al., "Sphallerocarpus gracilis polysaccharide protects pancreatic $\beta$-cells via regulation of the bax/bcl-2, caspase-3, pdx-1 and insulin signalling pathways," International Journal of Biological Macromolecules, vol. 93, Part A, pp. 829-836, 2016.

[75] H. Y. Lo, C. C. Li, F. Y. Chen, J. C. Chen, C. Y. Hsiang, and T. Y. Ho, "Gastro-resistant insulin receptor-binding peptide from Momordica charantia improved the glucose tolerance in Streptozotocin-Induced diabetic mice via insulin receptor signaling pathway," Journal of Agricultural and Food Chemistry, vol. 65, no. 42, pp. 9266-9274, 2017.

[76] R. Li, Y. Zhang, S. Rasool, T. Geetha, and J. R. Babu, "Effects and underlying mechanisms of bioactive compounds on type 2 diabetes mellitus and Alzheimer's disease," Oxidative Medicine and Cellular Longevity, vol. 2019, Article ID 8165707, 25 pages, 2019.

[77] Y. Wu, H. Lu, H. Yang et al., "Zinc stimulates glucose consumption by modulating the insulin signaling pathway in L6 myotubes: essential roles of Akt-GLUT4, GSK3 $\beta$ and mTOR-S6K1," The Journal of Nutritional Biochemistry, vol. 34, pp. 126-135, 2016.

[78] Y. Zhu, Q. Liu, Z. Zhou, and Y. Ikeda, “PDX1, Neurogenin-3, and MAFA: critical transcription regulators for beta cell development and regeneration," Stem Cell Research \& Therapy, vol. 8, no. 1, p. 240, 2017.

[79] P. A. Gerber and G. A. Rutter, "The role of oxidative stress and hypoxia in pancreatic beta-cell dysfunction in diabetes mellitus," Antioxidants \& Redox Signaling, vol. 26, no. 10, pp. 501-518, 2017. 